\title{
Peran Media Pembelajaran Berbasis Teknologi Informasi Dan Komunikasi Di Era Pandemi Covid-19
}

\author{
Veny Agustini Prianggita ${ }^{1}$ \\ Universitas Mathla'ul Anwar \\ Meliyawati ${ }^{2}$ \\ Universitas Mathla'ul Anwar \\ venyagustinibaby@gmail.com \\ meliyawati3@gmail.com
}

Received: 13 August 2021; Revised: 02 October 2021; Accepted: 24 December 2021
DOI: http://dx.doi.org/10.37905/aksara.8.1.147-154.2022

\begin{abstract}
Abstrak
Penelitian ini merupakan penelitian literatur yang membahas mengenai kondisi pendidikan di era pandemic covid-19, dimana pendidikan wajib berakselerasi tinggi dalam proses pembelajarannya. Teknologi bukan hal baru bagi masyarakat, tetapi perlu sebuah pengkajian mengenai perannya dalam pembelajaran. Sekolah, guru, siswa dan orangtua sama-sama dituntut untuk cepat menyadari peran penting dari media pembelajaran berbasis teknologi informasi dan komunikasi, selain hanya sebagai sentral dalam pembelajaran. Hasil dari penelitian literatur menunjukkan bahwa peran dari media pembelajaran berbasis teknologi informasi dan komunikasi yaitu semakin terbukanya kesempatan jangkauan secara luas, cepat efektif dan efisien terhadap ilmu pengetahuan baru dengan berbagai pengemasan dan penyebarluasan informasi serta memberikan keluasan peran kepada guru untuk mendesain belajar siswa dengan menekankan pada upaya penyiapan bahan pembelajaran yang menantang, penuh stimulus, tersistematis dan berkesinambungan. Sedangkan siswa diberikan keluasan untuk mengakses pembelajaran yang diberikan guru tersebut melalui kondisi yang didesain guru dan memungkinkan siswa untuk menggali pengetahuan tambahan sebagai pengayaan.
\end{abstract}

Kata Kunci: literatur, media pembelajaran, teknologi informasi dan komunikasi.

\begin{abstract}
This research is a literature study that discusses the condition of education in the era of the COVID-19 pandemic. Where education must accelerate high in the learning process. Technology is not new to society, but it needs an assessment of its role in learning schools, teachers, students and parents alike are required to quickly realize the important role of information and communication technology-based learning media other than just being central in learning. The results of the literature research show that the role of information and communication technology-based learning media is the opening of wide range of opportunities quickly, effectively and efficiently towards new knowledge by various packaging and disseminating information as well as roviding a broad role for teachers to design student learning by emphasizing efforts to prepare challenging learning materials, full of stimulus, systematic and continuous. while students are given the flexibility to access the learning provided by the teacher through conditions designed by the teacher and allow students to explore additional knowledge as enrichment.
\end{abstract}

Keyword: literature, learning media, information and communication technology

\section{PENDAHULUAN}

Pandemic covid-19 membuat dunia menjadi sepi. Tidak ada lagi suara tertawa dan riang anak-anak sekolah yang sedang bermain bahkan belajar di lingkungan sekolah, tidak ada lagi suara derap langkah guru menuju kelas untuk mendidik siswasiswanya, tidak ada lagi suara semangat ketika seseorang sedang mempresentasikan hasil penelitiannya dalam pertemuan-pertemuan ilmiah, bahkan tidak ada lagi suara deru mobil dan klakson yang bersautan dijalan karena macet. Semua kondisi ini 
membuat dunia layaknya tidak berpenghuni. inilah sisi kelam dari sebuah revolusi bumi tatkala meminta manusia untuk berhenti sejenak dari rutinitasnya setiap hari.

Tetapi bila dilihat dalam sebuah kacamata perkembangan teknologi, inilah saat dimana peradaban manusia melakukan akselerasi tinggi menuju sebuah peradaban baru. Peradaban yang meminta manusia untuk menjadikan teknologi sebagai alat bantu utama dalam berbagai aspek kehdupan tidak terkecuali pendidikan. Tuntutan tersebut menjadikan pandidikan sebagai salah satu sentral dalam penyesuaian proses pembelajaran yang tetap harus dilakukan oleh sekolah sebagai penentu kebijakan pembelajaran, guru sebagai perencana pembelajaran dan siswa sebagai subjek pembelajaran.

Teknologi dalam pendidikan sudah lama digaungkan sebagai salah satu peringatan penanda akan adanya perubahan dan inovasi dalam dunia pendidikan bahkan sejak memasuki abad 21. Sejalan dengan pendapat Rusman (2019) yang menyatakan:

"Kecenderungan perubahan dan inovasi dalam dunia pendidikan akan terus terjadi dan berkembang dalam memasuki abad ke-21 sekarang ini, dimana perubahan tersebut antara lain:lebih mudah dalam mencari sumber belajar, lebih banyak pilihan untuk menggunakan dan memanfaatkan ICT (Information and Communication Technology), makin meningkatnya peran media dan multimedia dalam kegiatan pembelajaran, waktu belajar lebih fleksibel, pengunaan pembelajaran berbasis computer, computer assisted instruction (CAI), penggunaan media televisi/video, mobile learning, e-learning, learning managemen system, kurikulum online, e-library, model belajar dengan system individual learning".

Kecenderungan perubahan dan inovasi tersebut akan memberikan implikasi luas dalam dunia pendidikan, dimana hal tersebut akan merubah tatanan dalam kurikulum, proses belajar dan pembelajaran, perubahan paradigma pembelajaran, ragam aplikasi program tekonologi pembelajaran dan tentu saja adanya tuntutan pengintegrasian teknologi Informasi dan Komunikasi (TIK) dalam kegiatan pembelajaran. Tuntutan pengintegrasian TIK itulah yang mengharuskan dunia pendidikan melakukan kreatifitas dan inovasi dalam proses pembelajarannya. Dalam kondisi seperti ini banyak sekali orang yang mengusulkan berbagai pembaruan dan aplikasi akan tetapi hanya sedikit yang berbicara mengenai bagaimana solusi dari pemecahan masalah dari pembaruan dan aplikasi tersebut.

Pembaruan dan aplikasi tersebut tentu saja merupakan sebuah upaya pemecahan masalah pendidikan dan pembelajaran terutama di era pandemic seperti saat ini, tetapi pembaruan dan aplikasi saja tidak cukup, tentunya memerlukan persyaratan minimal tersedianya beberapa hal berikut: a. adanya dukungan teknologi atau infrastruktur; $b$. penguasaan dan keterampilan dalam pemanfaatan teknologi dan mengembangkan materi serta bahan ajar; c. adanya kebijakan dari pemerintah dan pimpinan sekolah; $d$. kesiapan masyarakat.

Dalam hal ini penulis ingin membedah dengan rinci, bagaimana peran pembelajaran berbasis teknologi informasi dan komunikasi di era pandemic covid-19?. Dengan pemaparan yang akan disampaikan, penulis berharap dapat menemukan titik sentral peran dari pembelajaran berbasis TIK tersebut, sehingga dapat mengambil kesimpulan mengenai pemanfaatannya. 


\section{METODE PENELITIAN}

Metode penelitian yang digunakan yaitu metode penelitian literatur dengan jenis analisis isi, menurut Melfianora "yang dimaksud penelitian kepustakaan adalah penelitian yang dilakukan hanya berdasarkan atas karya tertulis, termasuk hasil penelitian baik yang telah maupun yang belum dipublikasikan". Dapat diartikan bahwa studi literatur merupakan sebuah penelitian yang membahas secara mendalam, mengenai isi suatu informasi tertulis dengan melakukan pengkajian yang menitikberatkan pada interpretasi bahan tertulis sesuai konteksnya.

\section{HASIL PENELITIAN DAN PEMBAHASAN}

Sejak Kementerian Pendidikan dan Kebudayaan menerbitkan Surat Edaran Nomor 4 tahun 2020 tentang Pelaksanaan Kebijakan Pendidikan dalam Masa Darurat Penyebaran Virus Corona, segala kegiatan pembelajaran di institusi pendidikan berubah menjadi pembelajaran jarak jauh atau pembelajaran daring (online). Menurut Luqman (2020) "implementasi kegiatan pembelajaran selama pandemi justru menjadi masalah baru, ketimbang sebuah kesempatan bagi tenaga pendidik dan institusi pendidikan mengadaptasikan diri dengan gagasan pendidikan daring sebagai realita pendidikan di abad 21".

Nampaknya masalah baru tersebut hadir karena adanya ketidaktauan atau ketidakpahaman pendidik mengenai media pembelajaran berbasis TIK, sehingga rasanya perlu sebuah kesempatan untuk memahamkan pendidik mengenai peran dari media pembelajaran berbasis TIK. Maka tulisan ini diharapkan dapat meminimalisasi ketidakpahaman pendidik terhadap hal tersebut.

Dalam kerucut pengalaman Edgar Dale (dalam Bambang, 2008) menyatakan bahwa:

"terdapat empat jenis pengalaman belajar, yaitu: a. mengamati dan berinteraksi dengan lambang verbal, contohnya mendengarkan ceramah; b. mengamati dan berinteraksi dengan mediated events, contohnya menonton slide power point, video, film; c. mengamati dan berinteraksi dengan actual events, contohnya fieldtrip, demonstrasi, sosiodrama; d. melakukan dalam pengalaman langsung, contohnya memasak, mencangkul, membuat karya, membuat video dan sebagainya".

Pemikiran Edgar Dale tersebut menimbulkan banyak pemikiran-pemikiran baru seperti James Finn yang berjasa dalam bidang komunikasi audio visual yang berkembang pesat dalam dunia teknologi pembelajaran saat ini. Gagasaan dari Finn tersebut dapat dikatakan penting untuk mengintegrasikan keterkaitan antara bahan belajar, proses pembelajaran serta pemanfaatan media dalam kegiatan pembelajaran. Menurut Euis Karwati (2015), menyimpulkan bahwa "belajar adalah sebuah proses perubahan didalam kepribadian manusia sebagai hasil dari pengalaman atau interaksi antara individu dengan lingkungan”. Sejalan dengan pendapat Rusman (2019) yang mengatakan:

"Belajar merupakan suatu aktivitas yang dapat dilakukan secara psikologis maupun fisiologis. Aktivitas yang bersifat psikologis yaitu aktivitas yang merupakan proses mental, misalnya aktivitas berpikir, memahami, menyimpulkan, menyimak, menelaah, membandingkan, membedakan, mengungkapkan, menganalisis dan sebagainya. Sedangkan aktivitas yang 
bersifat fisiologis yaitu aktivitas yang merupakan proses penerapan atau praktik, misalnya melakukan eksperimen atau percobaan, latihan, kegiatan praktik, membuat karya (produk), apresiasi dan sebagainya”.

Sehingga pada hakikatnya belajar merupakan sebuah proses interaksi edukatif yang mengarahkan individu kepada tujuan dan proses berbuat melalui berbagai pengalaman, kegiatan tersebut dinamakan pembelajaran. Kegiatan pembelajaran dilakukan oleh 2 orang pelaku yaitu guru dan siswa. Perilaku guru mengajar dan perilaku siswa belajar. Perilaku mengajar dan belajar tersebut dikaitkan oleh interaksi berdasar pada bahan pembelajaran atau materi dalam berbagai bentuk. Untuk dapat dikatakan berhasil melakukan proses pembelajaran, perlu adanya sebuah sistem yang mengandung beberapa komponen penting didalamnya, diantaranya: komponen tujuan, komponen bahan/materi, komponen media pembelajaran, komponen metode/strategi/teknik dalam belajar mengajar, dan komponen evaluasi. Komponenkomponen tersebut tidak bisa terpisah, artinya saling terkait, saling mempengaruhi antar komponen.

Salah satu komponen yang sedang menjadi pembahasan saat ini adalah media pembelajaran. Menurut Eko Triyanto (2013) "media pembelajaran secara umum adalah alat bantu proses belajar mengajar, segala sesuatu yang dapat dipergunakan untuk merangsang pikiran, perasaan, perhatian dan kemampuan atau keterampilan siswanya sehingga dapat mendorong terjadinya proses belajar". Sejalan dengan pendapat Rusman (2019) yang menyatakan:

"media pembelajaran merupakan salah satu alat untuk mempertinggi proses interaksi guru dengan siswa dan interaksi siswa dengan lingkungan dan seabagi alat bantu mengajar dapat menunjang penggunaan metode mengajar yang digunakan oleh guru dalam proses belajar".

Di era pandemik ini, pemahaman media pembelajaran tersebut menjadi sebuah jawaban dari bagaimana melakukan sebuah pembelajaran. Dengan adanya media pembelajaran, guru tidak lagi menjadi satu-satunya sumber belajar dalam kegiatan pembelajaran. Siswa dapat memperoleh berbagai informasi dari berbagai sumber belajar seperti televisi, radio, majalah, modul, computer, dan internet. Sekarang ini, di masa semakin maju ditambah dengan adanya pandemic membuat guru tidak hanya menjadi pengajar sebagai transfer of knowledge tetapi harus mampu berperan sebagai perancang/pengelola/manajer/fasilitator kegiatan belajar siswa dengan berbagai bantuan dan kemasan media dan sumber belajar. Bukan tidak mungkin bila dimasa depan media menjadi sumber informasi utama dalam kegiatan pembelajaran seperti adanya penerapan pembelajaran berbasis computer, sehingga guru perlu memliki keterampilan berpikir sebagai perancang pembelajaran dengan computational thinking (CT).

Menurut Ratna dkk (2019) "CT telah populer dalam beberapa tahun ini dan menjadi kemampuan penting untuk semua jenjang ilmu di dunia digital”. Menurut Wing dalam Ratna (2019) menjelaskan "bahwa CT sebagai kemampuan dasar berpikir untuk siswa dan guru serta memberikan cara berpikir baru untuk memecahkan masalah dan mengembangkan peluang". Berdasar hasil penelitian Ratna (2019) diperoleh:

"guru diharapkan dapat menerapkan pendekatan pembelajaran Computational Thinking sebagai alternatif untuk meningkatkan kemampuan pemecahan masalah peserta didik yang mampu juga untuk meningkatkan kemampuan 
berpikir kritis. Sekolah diharapkan dapat memfasilitasi terselenggaranya pembelajaran dengan menerapkan pembelajaran Computational Thinking sehingga peserta didik dan pendidik tidak mengalami kesulitan dalam mengadakan pembelajaran".

Pendekatan pembelajaran merupakan sebuah cara untuk dapat menurunkan strategi pembelajaran apa yang akan dipakai dan juga media pembelajaran yang akan dipakai. Salah satu media pembelajaran yang memungkinkan untuk dapat berkembang di era pandemic ini yaitu pembelajaran berbasis Teknologi Informasi dan Komunikasi (TIK). TIK pada hakikatnya adalah kajian ilmu dalam meningkatkan efektivitas melakukan komunikasi. Dalam perkembangannya, pendidikan memanfaatkan TIK untuk perbaikan dan peningkatan kualitas pembelajaran.

Penggunaan TIK dalam dunia pendidikan dikenal dengan program e-learning. Berkaitan dengan pemanfaatan e-learning difokuskan pada pemanfaatan computer, hal tersebut dikarenakan karena pemanfaatan computer dalam pendidikan telah sangat meluas dan menjangkau berbagai kepentingan pembelajaran. Guru dapat meningkatkan mutu pembelajaran dalam pemanfaatan perangkat lunak sebagai alat bantu pelaksanaan pembelajaran, sehingga siswa lebih mudah untuk belajar.

Perangkat lunak tersebut merupakan salah satu media dalam pembelajaran, ini sejalan dengan pendapat Pannen (2003) dalam Rusman (2019) menyatakan bahwa “ media dan teknologi pembelajaran di sekolah dalam arti luar yang mencakup perangkat keras (hardware), perangkat lunak (software), dan sumber daya manusia (humanware) yang dapat digunakan untuk memperkaya pengalaman belajar siswa". Euis (2015) pun berpendapat mengenai "media pembelajaran dapat diklasifikasikan menjadi media visual; media audio; media audio-visual; media cetak; media model; media realita; belajar benda sebenarnya melalui specimen; computer; multimedia; dan internet.

Dengan adanya pernyataan tersebut menegaskan bahwa media dalam pembelajaran memiliki fungsi sebagai alat bantu untuk memperjelas pesan yang disampaikan guru, baik saat siswa belajar bersama dengan guru atau belajar secara individu. Dalam pemanfaatan media sebagai alat bantu, Edgar Dale mengklasifikasikan menurut tingkat dari yang paling konkret ke yang paling abstrak. Berikut gambar dari kerucut pengalaman Edgar Dale:

\section{Gambar 1}

\section{Kerucut Pengalaman Edgar dale}

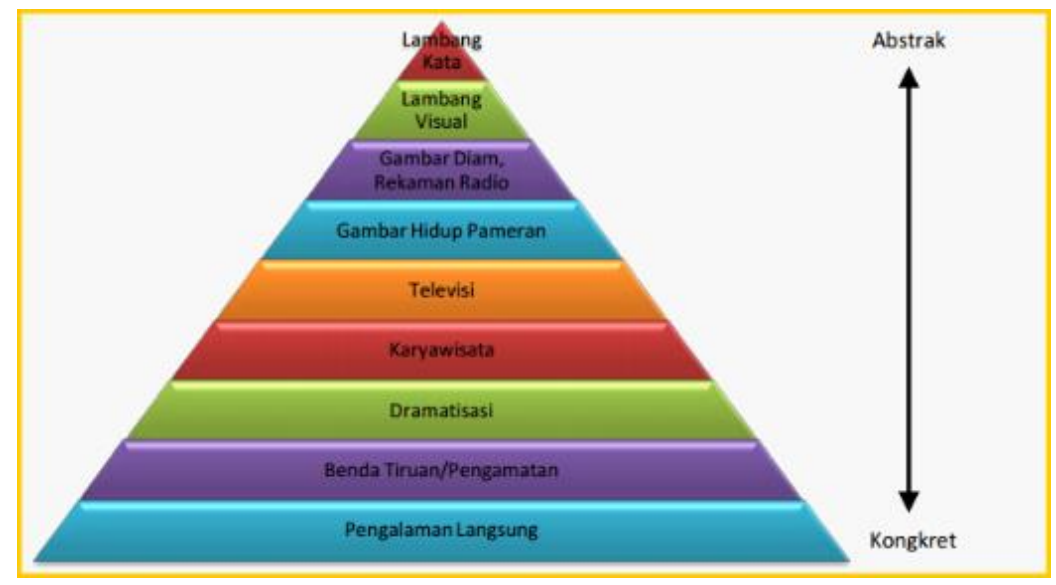


Berdasar pada kerucut pengalaman Edgar Dale tersebut, tergambar jelas bahwa media pembelajaran perlu dirancang secara tersistematis sesuai dengan tujuan pembelajaran dan diperlukan analisis terlebih dahulu sebelum dapat digunakan dalam proses pembelajaran. Sehingga terancang bahwa siswa harus lebih banyak melakukan kegiatan belajar, karena perlu adanya upaya untuk mengkondisikan siswa untuk tidak hanya mendengarkan uraian dari guru, tetapi juga melakukan aktivitas lain seperti mengobservasi, melakukan, membuat, mendemonstrasikan dan mengevaluasi.

Media pembelajaran yang dimaksud tersebut yaitu media pembelajaran berbasis teknologi informasi dan komunikasi atau biasa disebut dengan pembelajaran berbatuan computer dan aplikasi. Dimana pembelajaran tersebut memanfaatkan seluruh kemampuan computer yang terdiri dari gabungan hampir seluruh media, yaitu: teks, grafis, gambar, foto, audio, video dan animasi. Menurut Bambang (2008), menyatakan:

"seluruh media tersebut secara konvergen akan saling mendukung dan melebur manjadi satu media yang luar biasa kemampuannya. Salah satu keunggulan media computer ini yang tidak dimiliki oleh berbagai media lain, ialah kemampuannya untuk memfasilitasi interaktivitas peserta didik dengan sumber belajar (content) yang ada pada computer (man and machine interactivity)".

Menurut Rusman (2019) "penggunaan media pembelajaran berbasis TIK merupakan hal yang tidak mudah". Rasanya betul sekali pendapat tersebut, karena memang dalam penggunaannya perlu diperhatikan bagaimana agar media tersebut dapat dimanfaatkan semaksimal mungkin dan tidak menyimpang dari tujuan pembelajaran. Sejalan dengan pendapat Arief (1996) dalam Rusman (2019) mengatakan bahwa:

"Apabila ditinjau dari proses dan kesiapan pengadaan, media dikelompokkan dalam dua jenis, yaitu media yang dimanfaatkan atau digunakan oleh guru yaitu media yang sudah ada dipasaran dalam keadaan siap pakai atau siap digunakan oleh guru dan satu lagi media yang sengaja didesain atau dirancang oleh guru secara khusus untuk keperluan dan tujuan pembelajaran tertentu".

Sistem media pembelajaran TIK memberikan jangkauan yang luas, cepat, efektif dan efisien terhadap penyebarluasan informasi ke berbagai penjuru dunia. Ada berbagai media pembelajaran TIK, diantaranya: pembelajaran berbasis computer (CBI), pembelajaran berbasis web (e-learning), dan pembelajaran berbantukan computer. Sejalan dengan pendapat Budiman (2017) yaitu:

"Posisi TI sering disamakan dengan TIK atau bahkan dianggap lebih luas dibandingkan dengan TIK, sehingga sering salah dalam menentukan posisinya. TIK memiliki bidang kajian yang bermacam-macam, karena dalam TIK tidak hanya membahas masalah teknologi informasi dan komputer, tetapi juga membahas teknologi komunikasi/telekomunikasi”.

Dari pernyataan diatas dapat dikatakan bahwa media pembelajaran berbasis TIK merupakan media yang sengaja dibuat dan didesain sehingga dapat dimanfaatkan dalam kegiatan pembelajaran. Media pembelajaran berbasis TIK itu diantaranya:

\section{Pembelajaran Berbasis Komputer}

Menurut Euis (2015),

"Computer merupakan produk yang dihasilkan perkembangan zaman modern. Saat ini computer mendapat perhatian besar karena kemampuannya untuk mempermudah proses 
pembelajaran yang dibutuhkan peserta didik, terlebih lagi apabila dilengkapi dengan teknologi jaringan dan internet, maka penggunaan computer dapat menjadi primadona bagi peserta didik dalam proses pembelajaran. Beberapa kegiatan pembelajaran yang terkait dengan pembelajaran berbasis computer antara lain CAI (Computer Assisted Instruction) dan CMI (Computer Managed Instruction).

Menurut Rusman (2019), mengatakan "computer merupakan jenis media yang secara digital dapat menyediakan respons yang segera terhadap hasil belajar yang dilakukan oleh siswa. Lebih dari itu, computer memiliki kemampuan menyimpan dan memanipulasi informasi sesuai dengan kebutuhan. Perkembangan teknologi yang pesat saat ini telah memungkinkan computer memuat dan menayangkan beragam bentuk media didalamnya".

Tentu saja saat ini kita mengetahui bahwa computer sudah tidak lagi hanya digunakan sebagai alat pengolahan kata, tetapi juga sebagai alat multimedia yang memungkinkan siapapun membuat desain dan merekayasa suatu konsep dari ilmu pengetahuan. Selain dari itu perkembangan teknologi computer saat ini telah membentuk suatu jaringan (network) yang dapat memberi kemungkinan kepada guru untuk selalu memperbaharui ilmu pengetahuan yang dimiliknya serta memungkinkan siswa untuk bisa berinteraksi dengan sumber belajar secara lebih luas.

\section{Pembelajaran Barbantuan Komputer}

CAI merupakan pemanfaatan computer bagi guru untuk menyampaikan isi dari pelajaran, memberikan latihan/pelatihan, dan mengetes kemajuan belajar siswa secara langsung. CAI juga dapat dimanfaatkan sebagai tutor untuk dapat menggantikan guru menjelaskan materi. CAI memiliki berbagai bentuk, tergantung pada kecakapan perancang dan pengembang pembelajarannya, sehingga bentuknya bisa berupa permainan, mengajarkan konsep abstrak yang dikonkritkan melalui audio visual yang dianimasikan.

Sedangkan CMI biasa digunakan untuk membantu guru menjalankan fungsi administrative yang semakin meningkat, seperti rekapitulasi data siswa, data buku, pencatatan pembayaran, pencataan pengeluaran, dll. Sehingga untuk saat ini CAI dan CMI diintegrasikan dengan model pembelajaran elektronik atau e-learning dimana baik administrasi dan kegiatan

belajar mengajar sudah dalam satu system yang terintegrasi.

\section{Pembelajaran Berbasis Web (e-learning)}

E-learning menurut Dale (2012) mengacu pada pembelajaran melalui cara mengirimkan materi pengajaran secara elektronik. Istilah ini sering digunakan untuk mengacu pada jenis komunikasi elektronik apapun seperti video-conferencing, e-mail. E-learning merupakan jenis kegiatan belajar mengajar yang memungkinkannya tersampaikan materi pembelajaran kepada siswa dengan memanfaatkan media internet, intranet atau media jaringan computer lainnya.

Pemanfaatan internet sebagai media pembelajaran mengondisikan siswa untuk dapat belajar secara mandiri. Siswa dapat mengakses secara online dari database, museum, perpustakaan dan siswa mendapatkan sumber belajar primer mengenai berbagai bahan pembelajaran. Informasi-informasi tersebut diberikan oleh servercomputers yang dapat berasal dari commercial businesses (.com), government service 
(.gov), nonprofit organizations (.org), educational institutions (.edu), atau artistic and cultural groups (.arts).

Dalam hal ini, siswa dapat memiliki banyak peran dalam proses belajarnya. Dimana siswa dapat berperan sebagai peneliti dan analis, sehingga tidak hanya menjadi konsumen informasi saja. Dengan e-learning guru dan siswa tidak perlu hadir didalam kelas konvensional, siswa dapat melakukan analisis informasi yang relevan dengan pembelajaran dan juga melakukan pencarian yang sesuai dengan kehidupan nyata. Contoh penggunaan internet yang sudah digunakan oleh beberapa lembaga pendidikan seperti Universitas Terbuka, system aplikasi Kuliah Online Mathla'ul Anwar (KOMA) yang dalam penyelenggaraannya dosen dan mahasiswa mendapatkan modul untuk pemanfaatannya.

\section{KESIMPULAN}

Peran dari media pembelajaran berbasis TIK tersebut menjadi penting sejak memasuki abad-21, dimana manusia dituntut oleh perkembangan untuk mudah beradaptasi terhadap penyesuaian keilmuan sehingga dapat mempercepat laju cipta sumber daya manusia yang berkualitas. Dengan bantuan media pembelajaran berbasis TIK maka semakin terbuka kesempatan jangkauan yang luas, cepat, efektif dan efisien terhadap pencarian ilmu pengetahuan terbaru melalui pengemasan dan penyebarluasan informasi ke berbagai penjuru.

Hal inipun memberikan keluasan peran kepada guru untuk mendesain belajar siswa dengan menekankan pada upaya penyiapan bahan pembelajaran yang menantang, penuh stimulus, tersistematis dan berkesinambungan. Sedangkan siswa diberikan keluasan untuk mengakses pembelajaran yang diberikan guru tersebut melalui kondisi yang didesain guru dan memungkinkan siswa untuk menggali pengetahuan tambahan sebagai pengayaan.

\section{DAFTAR PUSTAKA}

Budiman, Haris. 2017. Peran teknologi Informasi dan Komunikasi Dalam Pendidikan. (Jurnal Pendidikan Islam, Al-Tadzkiyyah, Volume 8 No. I 2017). Hal 31.

Eko Triyanto, dkk. Peran Kepemimpinan Kepala Sekolah Dalam Pemanfaatan Media Pembelajaran Sebagai Upaya Peningkatan Kualitas Proses Pembelajaran.(Jurnal Teknologi Pendidikan Vol 1, No 2, 2013). hal 230

Hakim, Luqman. 2020). Pembelajaran dan Covid-19: Momentum untuk Perubahan. Rawamangun: Taman pembelajar.

Karwati, Euis, Donny. 2015. Manajemen Kelas. Bandung: Penerbit Alfabeta.

Ratna, Kunti dkk. 2019. Penerapan Computational Thinking untuk Meningkatkan

Kemampuan Berpikir Kritis Siswa Kelas X MIA 9 SMA Negeri 1 Surakarta pada Materi Usaha dan Energi 6. Jurnal Materi dan Pembelajaran Fisika (JMPF) Volume 9 Nomor 22019 ISSN: 2089-6158

Rusman, Deni, Cepi. 2019. Pembelajaran Berbasis Teknologi Informasi dan Komunikasi. Depok: PT. RajaGrafindo Persada.

Warsita, Bambang. 2008. Teknologi Pembelajaran. Jakarta: Rineka Cipta

Melfianora. Penulisan Karya Tulis Ilmiah Dengan Studi Literatur. Pekanbaru: UPT Balai Pelatihan Penyuluh Pertanian. 